Ehrlich records the concern of one psychiatrist that if antidepressant drugs were shown to be ineffective, patients would suffer by being deprived of the benefits of the placebo effect. A striking study, published last year, revealed that in PET scans the same region in the brains of patients became active whether they were given placebos or opioid-receptor drugs. What we clearly need, then, are better placebos.

There is a short story by the US humorist Josh Billings in which a farmer discovers that his black horses are eating more hay than his white horses. Eventually he gets to the root of the matter and finds the explanation: he has more black horses than white. The confusion of mind that Ehrlich exposes to view is often close to that of Billings's farmer.

Here and there I found myself wondering whether, in striving for objectivity, Ehrlich was not putting too much weight on publications of uncertain authority in dubious journals. All the same, he has dug consistently deep and marshalled the evidence in masterly style. He is unfailingly lucid, and if his colloquial, rather jokey manner brings his book more readers, then so much the better, for the lessons that it teaches are important to us all. It upholds, moreover, the principle enunciated by an academic politician of legendary dexterity, a famous British vice-chancellor: one must always keep scientists away from committees - they are apt to change their minds in response to the evidence.

Walter Gratzer is emeritus professor of biophysical chemistry, King's College London, the Randall Centre, Guy's Campus, St Thomas' Street, London SE1 1UL, UK

\section{Birds and the double elephant}

\section{Audubon's Elephant: The Story of John James Audubon's Epic Struggle to Publish The Birds of America}

by Duff Hart-Davis

Weidenfeld \& Nicolson: 2003.192 pp. £18.99

(to be published in the US by Henry Holt next April)

\section{Audubon in Edinburgh: And his Scottish Associates \\ by John Chalmers \\ National Museums of Scotland: 2003. \\ 240 pp. $£ 30$}

\section{David Knight}

John James Audubon's enormous Birds of America books (1827-38) could not be printed and published in his native United States — the skills available to produce a book of this size were available only in Europe. So Audubon travelled to Britain,

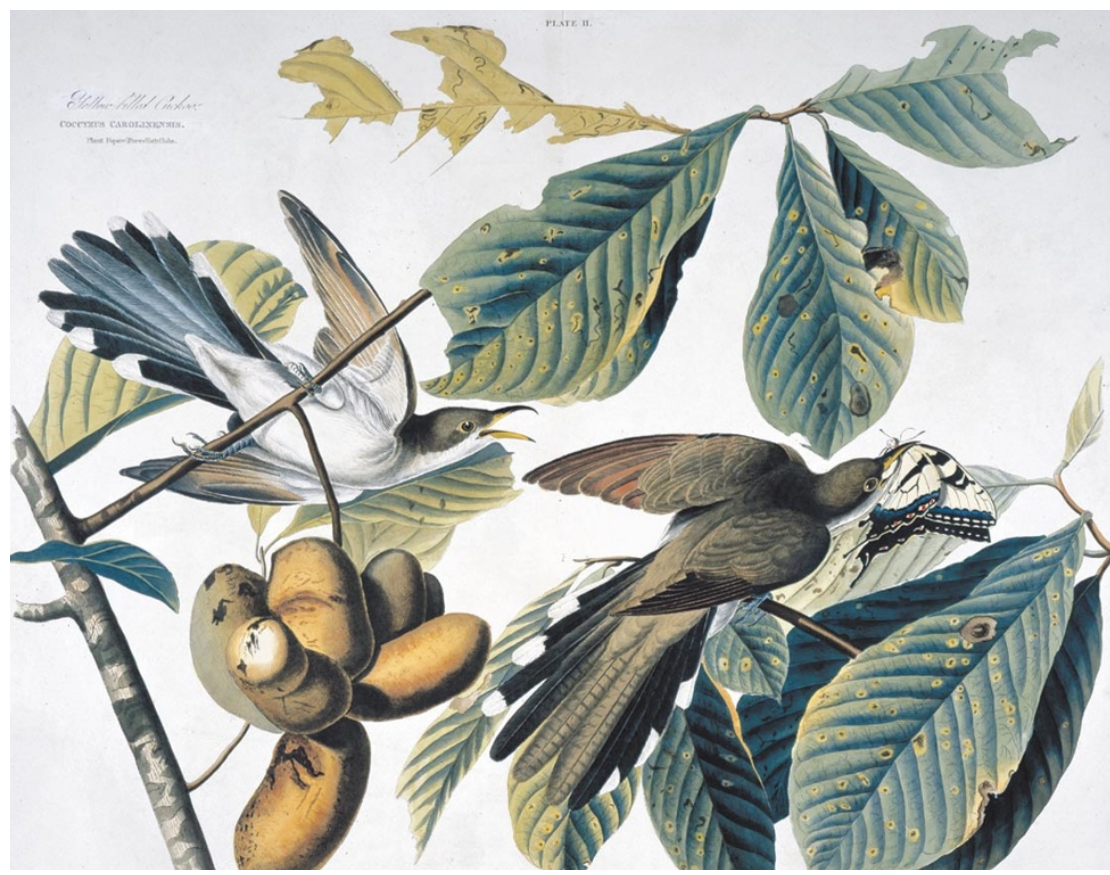

Huge undertaking: this yellow-billed cuckoo was life-sized in John James Audubon's Birds of America.

first to Liverpool and then on to Edinburgh, bringing with him his astonishing portfolio, which was big enough for all of the birds to be portrayed life-sized. Audubon in Edinburgh and Audubon's Elephant both focus on how the resulting extraordinary volumes of Birds of America, which now sell for millions of dollars, were produced. And they tell how Audubon recruited subscribers to fund the printing of successive volumes, a process that took more than a decade. It is a romantic story.

Audubon's volumes stand a metre tall the title of Hart-Davis's book refers to the size of the format, double elephant - and his work is marvellous, but is it science? Or is it, in fact, a white elephant? This question in part lay behind Audubon's rows with George Ord of the American Philosophical Society in Philadelphia and the eccentric traveller, squire and naturalist Charles Waterton in England, who considered him a charlatan. Clearly, Audubon was not that, even if his tales from the wild frontier about wildlife, ancestry and adventures improved in the telling. In line with the maxim "What's hit is history, but what's missed is mystery", Audubon slaughtered masses of his beloved birds in order to mount them convincingly and paint them.

Huge tomes sold in small editions are not the stuff of serious ornithology. This made Audubon's alliance with the Scottish naturalist William MacGillivray so important, although in print Audubon hardly seems to have done him justice. MacGillivray did the dissections and got the science right in the volumes of text, Ornithological Biography, that were published to accompany the plates. William Swainson had been in line for this job but had stuck out for fairer terms and broken off negotiations. Swainson was a leading illustrator and author of books on zoology, but his trinitarian (or quinarian) taxonomic system was coming to be seen as a speculative straitjacket on nature, and the book would have been poorer had it been saddled with it.

Audubon's life until 1826 had been a series of failures culminating in rows in Philadelphia where the memory of Alexander Wilson, his predecessor as America's leading ornithologist, was assiduously kept fresh. But despite his detractors, Audubon was elected to several scientific societies, including the Royal Society. The books by Hart-Davis and Chalmers both tell the tale of how this frontiersman, for whom English was a second language, managed to break into the scientific community through his energy, enthusiasm and sheer talent as a painter.

Finding friends and admirers in Liverpool, Audubon went to Edinburgh with more confidence. There he ignored advice to publish in a small format, and met William Lizars, who was to do some exquisite plates for William Jardine's series The Naturalist's Library. Lizars engraved and printed Audubon's plates and coloured them by hand - this was by necessity variable, and was a frequent source of complaint from the subscribers who sponsored the work. After producing a few of these, Lizars, faced with a strike and overstretched, was happy to give up.

Audubon, by then in London, found that Robert Havell and his son (also Robert) would do the job at a lower rate, and they ended up doing almost all of the plates. 
Audubon's was one of the last great books to be illustrated with engravings, as Swainson and others perfected the cheaper method of lithography. Each volume generally contained, unsystematically organized, some plates of one or two big birds, and some of several smaller ones. But Audubon struggled to maintain enough subscribers, as some died or fell away as the work progressed. Even so, he triumphed, even in the United States, to which he returned several times.

Audubon's Elephant and Audubon in Edinburgh both recount his eventful history.
But whereas Hart-Davis has produced a compact, elegant and readable biography, Chalmers' less-organized volume is focused as much on Edinburgh and its scientific world as on Audubon.

The size of Chalmers' book works better with Audubon's plates - the bigger the better, as he intended. And whereas HartDavis reprints only Audubon's pictures, Chalmers has also included many by other contemporary artists, so that we can compare their work and get a real feeling for Audubon's achievement. This also reveals the demands placed on anyone depicting nature at a time when Charles Darwin was a student.

Although most of the plates were printed in London, Audubon hated the bustling, foggy metropolis, but loved Edinburgh. Chalmers puts across a vision of that city and its medical institutions when Wordsworth's line "We murder to dissect" was being put into practice by Burke and Hare. The book places Audubon securely within the science of his time.

David Knight has taught the history of science at the University of Durham, UK, since 1964.

His latest book is Science and Spirituality: The

Volatile Connection (Routledge, 2003).

\section{Nasal bioluminescence in reindeer, Rangifer tarandus rubens}

\section{Martin Kemp}

Centre for Visual Studies, University of Oxford, Oxford OX12PT, UK

The discovery in 1939 of a reindeer mutant characterized by a luminescent snout (and popularly known as 'red-nosed') is a neglected chapter in the history of selective breeding. The mutation initially resulted in the young fawn (nicknamed Rudolph) being ostracized, in much the same manner as documented by H. Christian Andersen in his classic account of the so-called 'ugly duckling"1. However, the timely intervention of $\mathbf{S}$. Claus, who breeds reindeer in Russia's Chukotka peninsula, ensured the persistence of the new trait, which

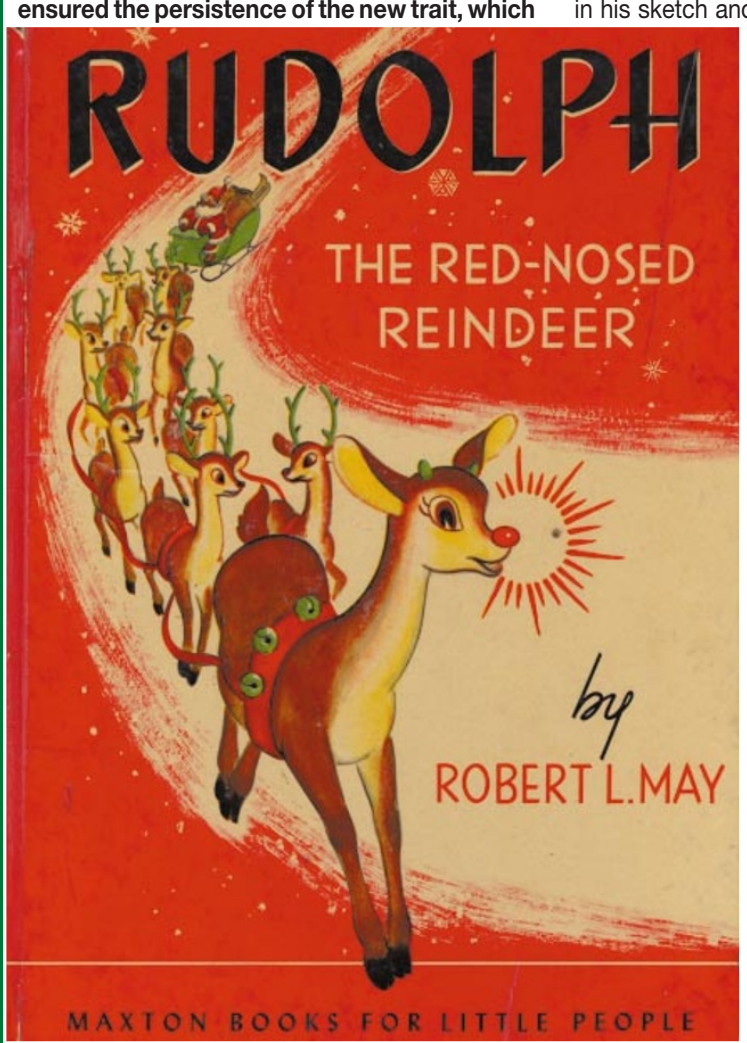

Figure 1 The first known recorded image of Rudolph, the red-nosed mutant of the reindeer, Rangifer tarandus rubens. has proved navigationally beneficial on a world-wide basis ${ }^{2}$. Here I show that the precise mechanism for the luminescence in the reindeer Rangifer tarandus rubens is identical to that which causes the glow in railroad worms.

There has been unwarranted confusion about the first record of the red-nosed reindeer. Priority belongs to R. L. May of the Montgomery Ward department store in Chicago, who made the first independent sighting, accompanied by draftsman D. Gillen, who clearly recorded its shining nose in his sketch and printed illustration ${ }^{3}$ (Fig. 1). The resulting publication was given the widest possible distribution, to such effect that six million copies had been sold by 1946 . The fame of the mutant was ensured by the popular, if inaccurate, musical rendition of its discovery by G. Autrey in 1949 .

It is now known that selection for the Rudolph mutant by the notoriously secretive Chukotkan herder, S. Claus, actually about came by chance, during a journey across the habitat occupied by the young reindeer ${ }^{4}$. Claus recognized that nasal bioluminescence presented a significant adaptive advantage in the prevailing meteorological conditions. The records for 25 December 1949 indicate a worldwide fog of unprecedented extent ${ }^{5}$. Claus' adoption of Rudolph and cultivation of a pure-breeding strain facilitated his navigational tasks during the smogs that beset developed countries in the 1950s and 1960s.

The famous red glow arises from a chemiluminescent reaction involving a direct conversion of chemical energy into light. It involves the substrate $D$-luciferin combining with ATP and oxygen, in a reaction catalysed by the enzyme luciferase, with light being given off along with the product oxyluciferin. The forms of luciferin and luciferase differ chemically in different organisms ${ }^{6}$, with the colour of light given off varying according to the substrate, ranging from blue in marine organisms to yellow in fireflies. The mechanism in $R$. t. rubens is identical to that seen in larva of the beetle Phrixothrix hiatus, known as the railroad worm, which produces red light from its head and green light from its body ${ }^{7}$.

The size of the current population of Rudolphs is impossible to estimate with any accuracy, but it must run into many millions. There have been proposals to classify the twentieth-century 'rednosed' subspecies as a pest ${ }^{8}$. However, a proper understanding of its natural history will almost certainly reveal that natural controls are already beginning to operate effectively.

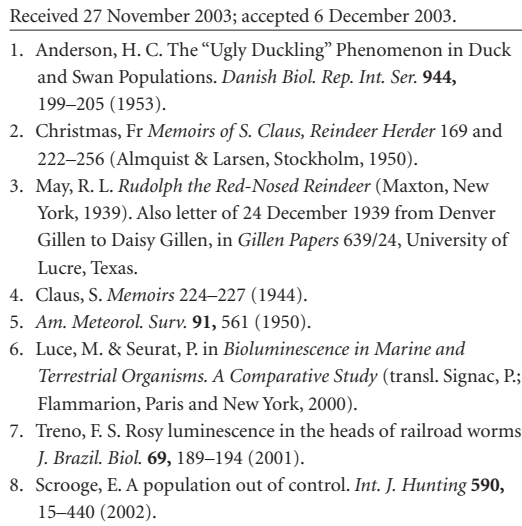

7. Treno, F. S. Rosy luminescence in the heads of railroad worms. J. Brazil. Biol. 69, 189-194 (2001).

8. Scrooge, E. A population out of control. Int. J. Hunting $\mathbf{5 9 0 ,}$ $15-440$ (2002)

Acknowledgements I thank A. Abbott for her work on catalysis, which she has shared with me. C. Dawnay provided vital support in helping me obtain PFD funding for this research.

Competing interests statement The author denies that he has any intention to obtain any financial interest in Rudolph.

Correspondence and request for materials should be addressed to the author (martin.kemp @trinity.ox.ac.uk). 